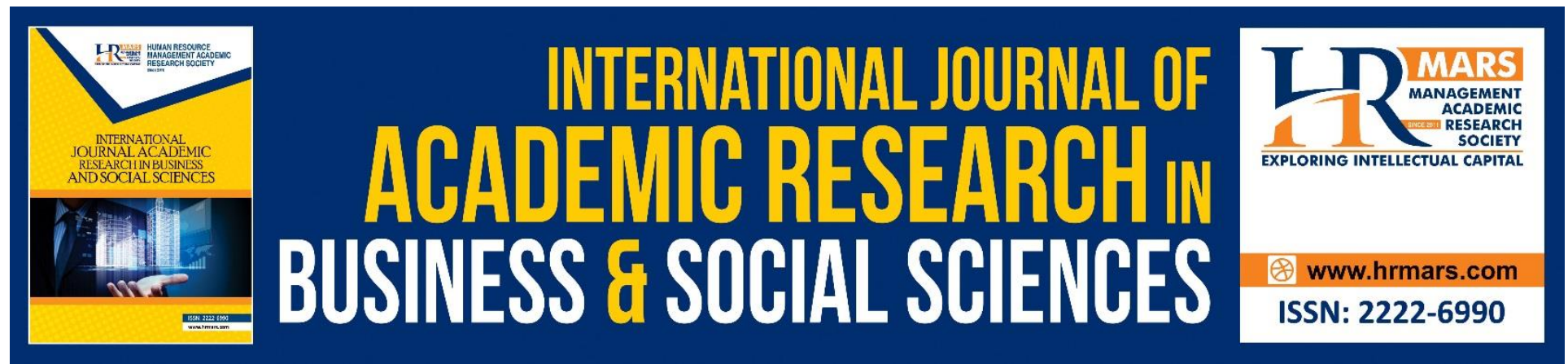

\title{
Determinants of Credit Risk in Islamic and Conventional Bank: Evidence from Malaysia
}

Norazwa Ahmad Zolkifli @ Uda, Mohamad Abdul Hamid, Hawati binti Janor

To Link this Article: http://dx.doi.org/10.6007/IJARBSS/v8-i6/4301

DOI: $10.6007 /$ IJARBSS/v8-i6/4301

Received: 23 May 2018, Revised: 19 June 2018, Accepted: 29 June 2018

Published Online: 02 July 2018

In-Text Citation: (Uda, Hamid, \& Janor, 2018)

To Cite this Article: Uda, N. A. Z. @, Hamid, M. A., \& Janor, H. binti. (2018). Determinants of Credit Risk in Islamic and Conventional Bank: Evidence from Malaysia. International Journal of Academic Research in Business and Social Sciences, 8(6), 1054-1068.

\section{Copyright: (c) 2018 The Author(s)}

Published by Human Resource Management Academic Research Society (www.hrmars.com)

This article is published under the Creative Commons Attribution (CC BY 4.0) license. Anyone may reproduce, distribute, translate and create derivative works of this article (for both commercial and non-commercial purposes), subject to full attribution to the original publication and authors. The full terms of this license may be seen

at: http://creativecommons.org/licences/by/4.0/legalcode

Vol. 8, No. 6, June 2018, Pg. 1054 - 1068

http://hrmars.com/index.php/pages/detail/IJARBSS

JOURNAL HOMEPAGE

Full Terms \& Conditions of access and use can be found at http://hrmars.com/index.php/pages/detail/publication-ethics 


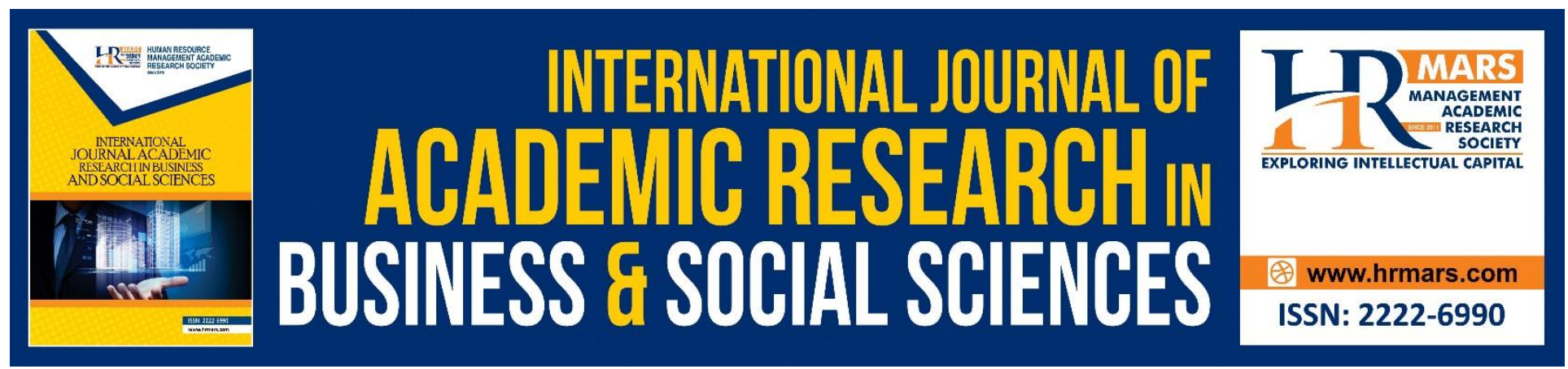

\title{
Determinants of Credit Risk in Islamic and Conventional Bank: Evidence from Malaysia
}

\author{
Norazwa Ahmad Zolkifli @ Uda \\ Institute of Malaysian and International Studies (IKMAS), Universiti Kebangsaan Malaysia, \\ Malaysia
}

Mohamad Abdul Hamid

Kulliyyah Muamalat, Kolej Universiti Insaniah, Malaysia

Hawati binti Janor

School of Management, Faculty of Economics and Management, Universiti Kebangsaan Malaysia, Malaysia

\begin{abstract}
Risks in banking have to be managed properly to ensure that banks can sustain in the financial industry. This paper examines the credit risk with the factors that influence risk in Islamic and conventional banking. This study highlights the relationship between credit risk and factors that affect the risks in both banking systems. The data have collected from financial statements of respective banks for a period of 9 years, starting from 2008 to 2016 and panel data analysis was used in this study. The findings of this study show that management efficiency and leverage indicate the lower efficiency and the higher debt that shows higher credit risk in both banking systems. Findings from this research contribute in enriching and enhance literature on risk management of Islamic and conventional banks. The problem of credit risk regarding regulatory requirement will decrease and this will give banks to increase their profitability and improve their financial performance.
\end{abstract}

Keywords: Credit Risk, Islamic Bank, Conventional Bank, Risk Management

\section{Introduction}

Risk management has become more important after the economic and financial crisis that invades United States when Lehman Brothers Holdings, Inc filed for bankruptcy on 15 September 2008. Failure of risk management is one of the causes of this crisis. As a continuous process, risk management depends directly on the internal and external environment in banks. Effective risk management is a very important for the organization, including financial institutions. Financial institutions cannot operate properly without an effective system. In fact, financial institutions 
required an effective risk management system in order to develop a strong and stable infrastructure of financial institutions. Banking and financial institution also affected because the global financial crisis in the year 2007-2008 (Vaaler \& McNamara, 2004). The effect of these economic conditions of most countries decreases and have destroyed several banking institutions that have survived in the market to undermine public opinion against the banking system is considered stable. Islamic and conventional banks also faced this problem, but when compared with conventional banking, Islamic banking still can survive from this crisis with only a minimal impact. Theoretically in previous research suggest that Islamic banking is more risky than conventional bank in some other aspect, but there is still a lack of empirical research about this study. According to Khan and Ahmed (2001) related to risk management, explained that Islamic financial institutions are faced with a number of risks that are different from conventional financial institutions. This shows that both banks have a serious risk problem in risk management.

Credit risk is a very important risk in banking system. It is normally defined as the probability of a borrower in default a loan commitment in the banking system. Credit risk involves the inability or failure of one party to meet its obligations as agreed upon signing the contract (Al-Saati, 2003). According to Bhatti and Misman (2010) credit risk exists in all products that the bank offered to the customers and each bank have a different risk depend the way they manage the risk. Credit risk is one of the main risks that seriously affect bank when financial crisis in 1997 happened. Studies conducted by Rekha and Kotreshwar (2005) show that credit risks were accounted for $70 \%$ of the total risk in the bank and $30 \%$ for market risk and operational risk. Managers of commercial banks realize that credit risk is the risk of the most common problems in the banking business (Carey \& Stulz, 2005). While Khan and Ahmed (2001) explain credit risk is the most important source of banking instability is widespread and widely capital than bank insolvency. Basel Accord, the International Bankers Association also noted that the largest source of risk in the banking problem is credit risk which is the risk that caused by human carelessness. This study examines the relationship between credit risk and the factors that affect risks in both banking systems.

This paper is divided into six sections. This paper begins with an introduction and followed by section 2 entails review of related literature based on this study. Section 3 highlights the methodology and section 4 present the analysis the result of the paper. Finally, section 5 concluded the paper with the contribution of the study.

\section{Literature Review}

Credit risk is the potential loss due to the failure of the counter party lenders to meet its financial obligations and very important to banks as it is an integral part of the loan process. The purpose of credit risk is to ensure that the structures and processes of credit risk management can maintain and further improve the bank's risk assessment capabilities in key areas of credit within acceptable parameters. According to Hussain and Al-Ajmi (2012) credit risk is the most important risk in Islamic bank. The effectiveness of credit risk management is a very difficult component and need a comprehensive technique in the banking system. Hanif et. al (2012) found that credit risk management and solvency is a performance of Islamic banking is preferable than conventional bank. This show that credit risk is a factor of the performance of the banking system and it becomes more popular in financial analysis. 
Study on impact of credit risk management on the financial performance of bank in Kenya for the period 2000-2006 by Musyoki and Kadubo (2012) were found that credit risk is an important predictor of bank performance while the success of bank performance depend on risk management to extent around $36 \%$. They suggest putting more emphasis on risk management in order to minimize risk and maximize performance, the bank need to allocate more funds to default rate management.

Financial crisis in 1997 clearly demonstrated the importance of credit risk in both types of bank and how it touches upon bank viability. Studies that compare between conventional and Islamic bank in regard to the effect of credit risk on each bank performance are Hassan and Bashir (2003), Ahmad and Ahmad (2004), Kahf (200), Vitria (2008) and Aldoseri (2012).

According to Hassan and Bashir (2003), Islamic bank found their loans to be low in risk compare than conventional bank in their sample tent to have more loan loss reserve and bad loan relative to the total loan. The sample included 43 Islamic banks for 8 years in 1994-2001 from 21 countries. Kahf (2005) argues that Islamic bank has qualitatively similar credit risk to conventional banks, but the processes of the calculation of the minimum equity requirement for credit risk should not be different from the methodologies proposed for conventional banks. This shows that both banks have a similar process in managing credit risk in banking.

Ahmad and Ahmad (2004) examine the problem in credit risk faced by conventional and Islamic bank is a principle factor that influences the formation of credit risk in an operation of Islamic banks. The data extract from audited annual report, income statement and balance sheet of 6 anchor bank in Malaysia from 1996 to 2002. Finding from this study support the intuition with empirical evidence that there are significant differences between the means credit risk predictors of Islamic bank and conventional bank. The efficiency in managing the risky assets is crucial to minimize credit risk by strengthening internal control and minimizing adverse selection to increase efficiency credit risk within Islamic bank.

Further, Vitria (2008) found that the significant factors related to credit risk in Islamic bank are management efficiency, leverage, loans to risky sectors, regulatory capital, risk weighted asset and growth in total asset. The study covered commercial bank in Indonesia with Islamic finance has lower credit risk, but have higher profit rate risk and liquidity risk.

Aldoseri (2012) investigated that conventional and Islamic bank does not have significant differences in credit risk exposure. They found credit risk have a positive relationship with leverage in Islamic bank and loan to deposit ratio in conventional bank, but the size of Islamic bank has a negative relationship in Islamic banking and management efficiency in conventional bank. This show that credit risk in Islamic and conventional bank sis not serious rather than others risk in banking.

Previous study done by Waemustafa and Sukri (2015) found that bank specific determinants of credit risk are uniquely influenced the credit risk formation in conventional and 
Islamic banks. Their study found that risky sector financing and regulatory capital are significant to credit risk for Islamic banks but for conventional banks only loan loss provision, debt to equity ratio, size, regulatory capital are significant factors to credit risk. This shows that there is a difference between credit risk determinants between Islamic banks and conventional banks.

Salim et al. (2016) used a proxy for credit risk is Non-performing loans (NPLs) and found that credit risk in Iranian banks generally exhibited efficiency improvements over time and their credit risk performance deteriorated considerably after the regulatory changes introduced in 2005.

\section{Methodology}

\section{Data}

Data from the income statement and balance sheet of 16 Islamic banks and 21 conventional banks from 2008-2016 was used in this study.

\section{Credit Risk Model}

Credit risk models used in this study was based on a study made by Aldoseri (2012), Rahman (2010), Ahmad and Ahmad (2004), Madura et. al (1994) and Hassan (1993). The research model is as follows:

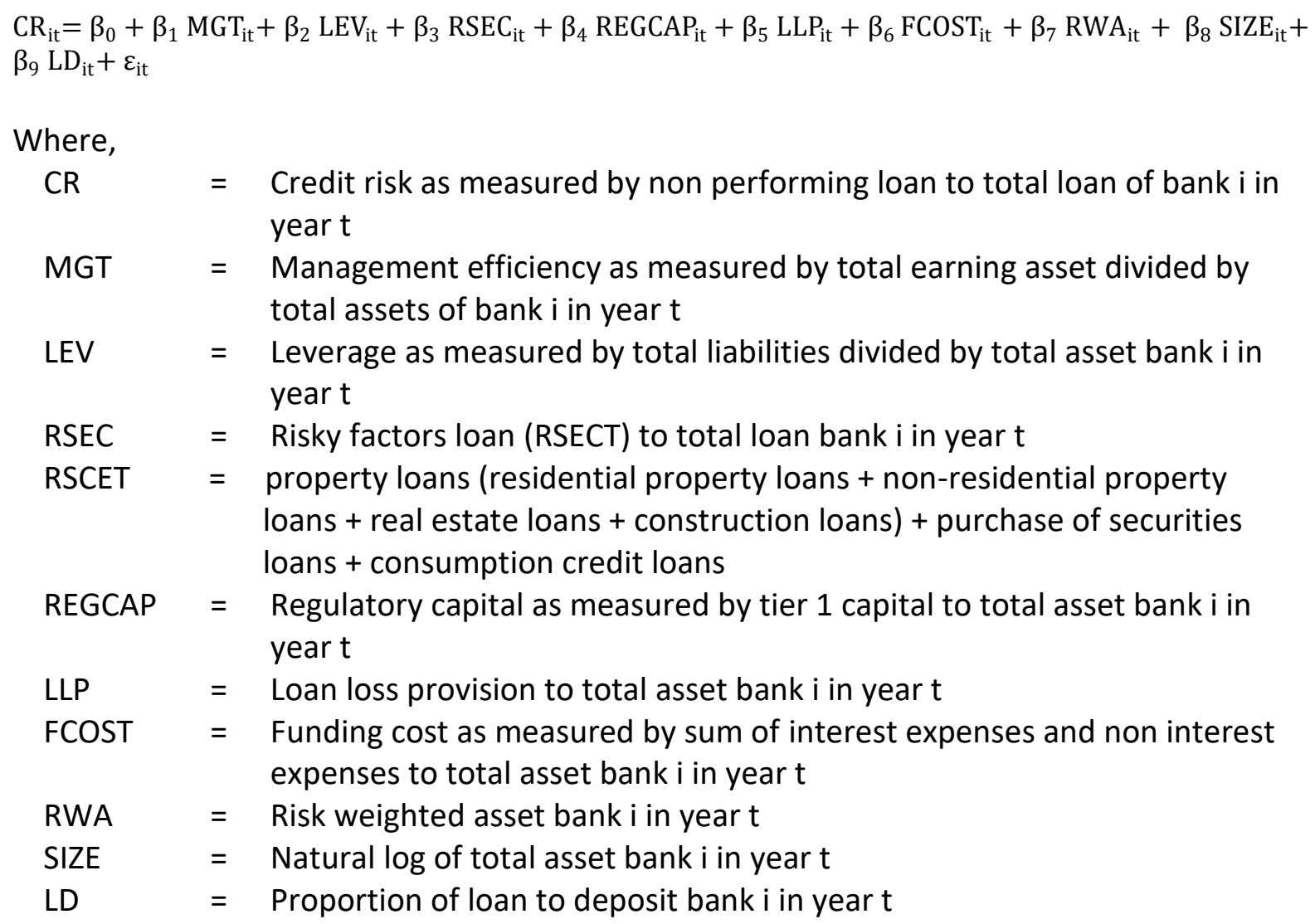


The credit risk variable is represented non-performing loans to total loan. (Aldoseri, 2012; Vitria, 2008; Ahmad \& Arif, 2004; Corsetti et. al, 1998; Berger \& DeYoung, 1997. From the literature, there are nine variables that determine credit risk in banking. The variable is management efficiency (MGT), Leverage (LEV), risky loan sector (RSEC), regulatory capital (REGCAP), loan loss Provision (LLP), funding costs (FCOST), risk weighted assets (RWA), natural log of total assets (SIZE) and the proportion of loan-deposit (LD).

\section{Hypotheses Development}

Based on the theoretical framework explained in the previous section, the following hypotheses have been developed:

$\mathrm{H}_{0}$ : There is no significant relationship between credit risk and the factor that influence risk in Islamic and conventional bank.

$\mathrm{H}_{1:}$ There is a significant relationship between credit risk and the factor that influence risk in Islamic and conventional bank.

\section{Empirical Result}

This section presents the descriptive analysis, regression model for credit risk and factor that affected risk. GLS and regression panel data were used in this study. According to Gujarati (2003) GLS estimation will help to tackle the issue of non-normality distribution of the variable, which may be due to the presence of heteroscedasticity. Wooldridge (2002) explains that GLS turn out to be asymptotically more efficient than the OLS method. One way to take into account the individuality of each bank to cross sectional is by letting the intercept vary for each bank, but each bank still assume that the slope coefficients are constant across banks. The intercept in the regression model differs among individuals in the fixed effect model. The intercept differs among the banks because each bank has some specific characteristics of its own. According to Lobo and Yang (2001), pooling the cross sectional data over the sample period cannot produce a minimum standard error because the amount of observation increase relative to each bank's observation and at the same time the number of firm dependent and time dependent intercept will be estimated. Beaver et al. (1989) focus on the advantages of the fixed effect model. First, as far as the residual correlation are influenced by such fixed effect, the estimation can produce regression residuals with considerably lower inter-correlation, that a greater estimation efficiency and unbiased standard error. On the other hand, to the extent the intercepts will reflect the effects of correlated omitted variables, the slope coefficient of the explanatory variables is less exposed to bias from this source.

\section{Descriptive Statistic}

Table 1 presents the results of credit risk for descriptive statistics of the conventional banks. Credit risk (CR), which is derived by dividing non performing loan with total asset, has a means and a medium ratio of 0.49 and 0.58 . This suggests that conventional banks have on average a credit risk ratio of 0.49 . Management efficiency (MGT) is measured by earning asset to total asset has score mean of 0.43 , median of 0.36 and standard deviation of 0.18 . This shows that management efficiency has an average of 0.36 among the bank in the sample. This result also shows the means of leverage (LEV) is 0.89 and median of 0.91. Base on standard deviation, 
there is a significant dispersion in leverage among banks. The mean and median of RSEC which is defined by the risky loan sector to total loan is 0.41 . This show that RSEC ratio is on average is 0.41 same with median. Descriptive statistic also discovered the standard deviation for RSEC is 0.19. It indicates that there are banks with the positive risky loan sector in bank loan as well as those with negative risky. This result also reported that RECGAP as measured by Tier 1 capital to total asset score a mean of 0.11 and median of 0.09. The mean and median of Loan Loss Provision (LLP) measured by Loan Loss Provision to Total Asset is 0 . The ratio of average funding cost (FCOST), which is measured from sum of interest expenses and non interest expenses divided by total asset is 0.03 with a median of 0.03 and standard deviation is 0.008 . The result also shows that risk weighted asset (RWA) have mean and median ratios of 6.95 and 7.36. The descriptive statistic of bank SIZE suggests that bank on average have 7.39 with a median of 7.61 and the standard deviation is 0.67 . Proportion of loan to deposit (LD) has score mean of 0.66 and median of 0.71 meanwhile the standard deviation is 0.35 . This shows that the proportion of loan is a significant dispersion among the bank.

\begin{tabular}{lccc}
\multicolumn{3}{l}{ Table 1: Descriptive statistic for the Conventional bank } \\
\hline Variable & Mean & Median & $\begin{array}{c}\text { Standard } \\
\text { Deviation }\end{array}$ \\
\hline CR & 0.4851 & 0.5774 & 0.2222 \\
MGT & 0.4312 & 0.3593 & 0.1794 \\
LEV & 0.8883 & 0.9079 & 0.0569 \\
RSEC & 0.4142 & 0.4100 & 0.1891 \\
RECGAP & 0.1106 & 0.0884 & 0.0570 \\
LLP & 0.0022 & 0.0020 & 0.0018 \\
FCOST & 0.0327 & 0.0332 & 0.0086 \\
RWA & 6.9530 & 7.3624 & 1.3917 \\
SIZE & 7.3933 & 7.6055 & 0.6733 \\
LD & 0.6554 & 0.7103 & 0.3504 \\
\hline
\end{tabular}

Table 2 presents the result of descriptive statistics on credit risk for Islamic bank. Credit risk (CR), which is derived by dividing non performing loan with total asset, has a means and a medium ratio of 0.55 and 0.58 . This suggests that Islamic bank has on average a credit risk ratio of 0.55. Management efficiency (MGT) is measured by earning asset to total asset has score mean of 0.45 , median of 0.42 and standard deviation of 0.17 . This shows that management efficiency has an average of 0.45 among the bank in the sample. This result also shows the means of leverage (LEV) is 0.90 and median of 0.92. Base on standard deviation, there is a significant dispersion in leverage among banks is 0.11 . The mean and median of RSEC which is defined by the risky loan sector to total loan is 0.53 and 0.51 . This show that RSEC ratio is on average is 0.53 with a median of 0.51. Descriptive statistic also discovered the standard deviation for RSEC is 0.29. It indicates that there are banks with the positive risky loan sector in bank loan as well as those with negative risky. This result also reported that RECGAP as measured by Tier 1 capital to total asset score a mean of 0.08 and median of 0.07. The mean of Loan Loss Provision (LLP) measured by Loan Loss Provision to Total Asset is 0.006 and the median is 0.004 . This show that average of Loan Loss Provision is 0.006 with a standard deviation of 0.009 . The ratio of average 
funding cost (FCOST), which is measured from sum of interest expenses and non interest expenses divided by total asset is 0.02 and median also 0.02 with standard deviation is 0.01 . The result also shows that mean and median for the risk weighted asset (RWA) is 6.72 and 6.87 with standard deviation is 0.85 . The descriptive statistic of bank size (SIZE) suggests that bank on average have 7.15 with a median of 7.08 and the standard deviation is 1.03. Proportion of loan (LD) to deposit has scored a mean of 0.89 and median of 0.79 while the standard deviation is 0.73 . This shows that the proportion of loan is a significant dispersion among the bank. These finding shows that the sample data are not normally distributed based on the result of descriptive statistic.

Table 2: Descriptive statistic for the Islamic bank

\begin{tabular}{lccc}
\hline Variable & Mean & Median & $\begin{array}{c}\text { Standard } \\
\text { Deviation }\end{array}$ \\
\hline CR & 0.5488 & 0.5764 & 0.1498 \\
MGT & 0.4501 & 0.4155 & 0.1738 \\
LEV & 0.9032 & 0.9248 & 0.1107 \\
RSEC & 0.5333 & 0.5106 & 0.2860 \\
REGCAP & 0.0823 & 0.0731 & 0.0411 \\
LLP & 0.0064 & 0.0045 & 0.0092 \\
FCOST & 0.0175 & 0.0166 & 0.0115 \\
RWA & 6.7196 & 6.8655 & 0.8544 \\
SIZE & 7.1525 & 7.0768 & 1.0297 \\
LD & 0.8891 & 0.7881 & 0.7322 \\
\hline
\end{tabular}

Figure 1 shows the different between the mean of credit risk for Islamic and conventional banks in Malaysia. When comparing their NPL, at year 2008 both banks have a same mean but starting 2009 Islamic banks have increased their NPL until 2010. Conventional banks decrease the NPL and go up again in 2010. In 2011 NPL for Islamic banks decreases and it's going up at 2012 but NPL for conventional banks are static since 2010 until 2012. This indicates that Islamic banks have a high credit risk compare to Conventional banks. The bank will make a financial decision based on risk analysis and if the credit risk have problem to manage this show that the bank should have a good credit risk management to make sure they can sustain in the industry. 


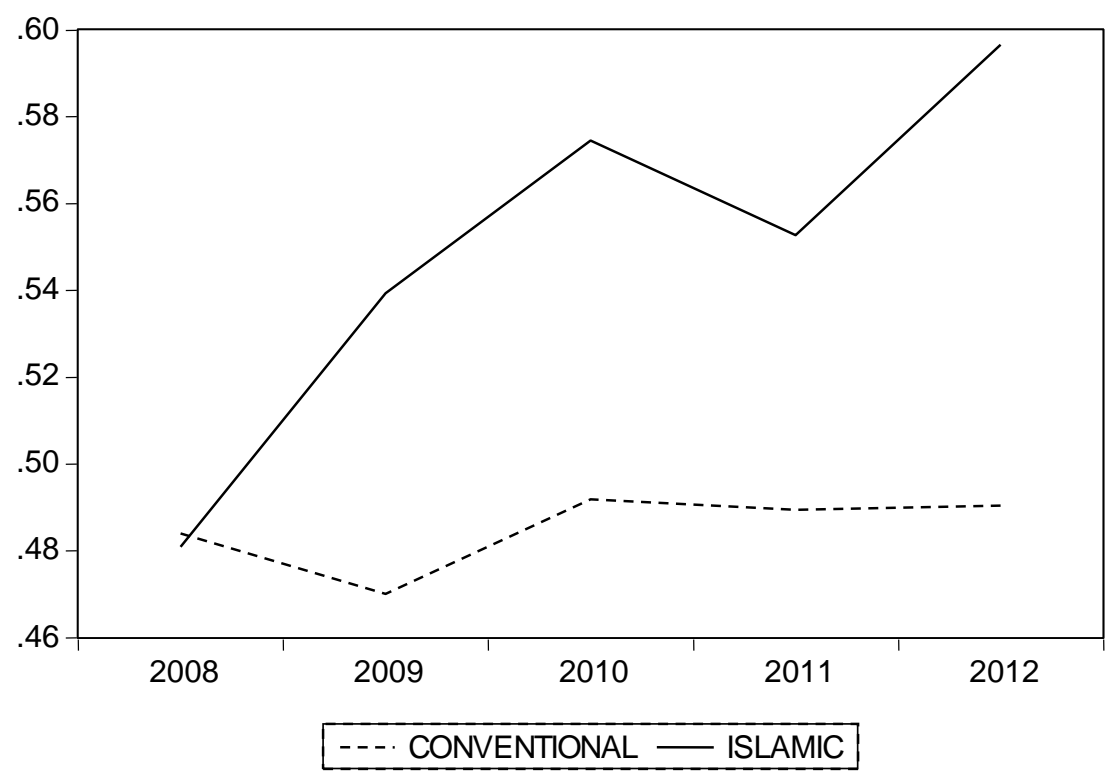

Figure 1: Credit risk between Islamic and conventional bank using NPL

\section{Tests of Multicollinearity}

Pearson's correlation uses to test multicollinearity for the equation. Table 3 shows the Pearson's correlation result for the Conventional banks. All variables in conventional banks are significant in explaining the relationships with credit risk except the variable REGCAP are not significant. The results also show that MGT and LD are strongly correlated with CR with a correlation value of -0.8946 and 0.8648 respectively. In fact, this variety is alternately analyzed in the regression estimation because of the VIF results show that the entire variable is not more than 10. The result of VIF plays an important role in the case of consistent findings. Banks respond positively with credit risk variable. While LEV, RSEC, LLP, FCOST, RWA, SIZE and LD have positive sign, but MGT and REGCAP have negatively significant related to credit risk. MGT and LD are strongly correlated with CR with a value of -0.8946 and 0.8648 . Table 4 shows the Pearson's correlation result for Islamic banks. The significant variables in Islamic banks are MGT, LEV, RWA and LD, while variable RSEC, REGCAP, LLP, FCOST and SIZE are not significant. The result also shows the variable MGT and LEV are strongly correlated with CR with a value of 0.8839 . This variable still is used in regression estimation because of VIF result shows the value is not more than 10. Overall, none of the variable shows a serious multicollinearity problem in the model. This proves that all variables are very important element of credit risk in conventional and Islamic banks.

\section{Regression Analysis}

The result of the GLS estimation of credit risk model is presented in Table 5, in the conventional and Islamic banks. Six variables such as MGT, LEV, RSEC, FCOST, SIZE and LD are significantly related to credit risk for conventional banks. Management efficiency (MGT) is negatively significant related to credit risk. This result shows that bank with lower efficiency in managing earning asset will give the higher risk in the banking system. This result supports the past findings 
from Vitra (2008). Leverage (LEV) is negatively significant related to credit risk and same with finding from Ahmad and Ahmad (2004) and Berger and DeYoung (1997). The regression result shows that risky loan sector (RSEC) has a negative and significant sign for conventional banks. This result shows bank with a lower financing, extended to risky sectors will face a high credit risk. A result from Ahmad and Ahmad (2004), Waemustafa and Sukri (2015) and Vitria (2008) has a positive relationship between risky sectors and credit risk in banking system that contrary to this result. However, according to Sundararajan and Errico (2002) Islamic banks have no legal means to control the client who manage the financed through mudaraba contract because they have a freedom to do and make their own decision. Because of this reason bank have to be more cautious in giving loans to customers, especially in risky sectors that can impact to credit risk exposure. The funding cost (FCOST) is positively significant with a credit risk in conventional banks. This indicates that conventional banks have high overhead in controlling and monitoring of problem loan with credit risk. The past finding from Ahmad and Arif (2004) and Ahmad and Ahmad (2004) found that FCOST are not significantly related to credit risk for both banking systems. Result of risk weighted asset (RWA) is not significant with credit risk in conventional banks. But Berger \& DeYoung (1997), Ahmad (2003), Ahmad and Ahmad (2004) and Vitria (2008) found that Risk Weighted Asset (RWA) has a positive relationship with credit risk in conventional and Islamic bank. This evidence shows that higher proportion of risky assets to total asset tend to have higher credit risk. Bank size (SIZE) for conventional bank has a positive sign and significant related to credit risk. This indicates that bank with larger bank size are higher to expose a credit risk. This result is consistent with Aldoseri (2012), Berger \& DeYoung (1997), Park (1997) and Shrieves and Dahl (1992) found that bank size has a positive relationship with credit risk. Result for Loan to deposit (LD) is positive and significant for conventional banks with credit risk. This positive sign support by Ahmad and Ariff (2007) which are show that ratio of credit risk is high of an amount of deposit in earning asset. The larger bank loan in portfolio will give a higher probability of loan default. This research will use the loan to deposit (LD) measured by Proportion of loan to deposit has significant positive to determinant of credit risk in banking system. (Aldoseri, 2012; Ahmad and Ariff, 2007; Ariff, 1988).

Islamic Banks have five variables that significantly related to credit risk which is MGT, RSEC, RWA, SIZE and LD. MGT, RSEC and SIZE have a negatively significant with credit risk. RWA and LD have a positively significant related with credit risk. This shows that Islamic banks also faced a credit risk and all variable that tested in this paper are have a strong correlated at $1 \%, 5 \%$ and $10 \%$ significant level. MGT has a negative correlation and same result with past finding from Vitria (2008). Ahmad and Ahmad (2004), and Vitria (2008) has a positive relation between risky loan sectors and credit risk in banking system and result from this research have a negative relationship at 5\% significance level. Risk weighted asset (RWA) has a positive relationship with an Islamic bank at $1 \%$ significance level. This shows that RWA are very strongly related to credit risk. For Islamic banks, SIZE has a negatively significant related with credit risk. This shows that bank with small asset is higher to expose to credit risk. Proportion of loan to deposit has significant positive with credit risk in Islamic banks and this shows that larger bank loan in portfolio will give a higher probability of loan and bank will face a credit risk. 
INTERNATIONAL JOURNAL OF ACADEMIC RESEARCH IN BUSINESS AND SOCIAL SCIENCES

Vol. 8, No. 6, June 2018, E-ISSN: 2222-6990 @ 2018 HRMARS

Table 3: Pearson Correlation for Conventional bank

Correlation for Conventional bank

\begin{tabular}{|c|c|c|c|c|c|c|c|c|c|c|}
\hline & CR & MGT & LEV & RSEC & REGCAP & LLP & FCOST & RWA & SIZE & LD \\
\hline CR & 1.0000 & & & & & & & & & \\
\hline MGT & $-0.8946^{*}$ & 1.0000 & & & & & & & & \\
\hline LEV & $0.4284^{*}$ & $-0.4966 *$ & 1.0000 & & & & & & & \\
\hline RSEC & $0.2887^{*}$ & $-0.1828 * *$ & 0.0588 & 1.0000 & & & & & & \\
\hline REGCAP & -0.4030 & 0.1104 & $-0.5391 *$ & $-0.2564 *$ & 1.0000 & & & & & \\
\hline LLP & $0.4516^{*}$ & $-0.3790 *$ & $0.1995^{* *}$ & 0.1848 & $-0.1958 * *$ & 1.0000 & & & & \\
\hline FCOST & $0.3855^{*}$ & $-0.3387^{*}$ & $0.4034^{*}$ & 0.1586 & $-0.2678 *$ & $0.4793 *$ & 1.0000 & & & \\
\hline RWA & $0.2707^{* *}$ & $-0.3051^{*}$ & $0.2911^{*}$ & 0.0798 & -0.1149 & 0.1761 & 0.1798 & 1.0000 & & \\
\hline SIZE & $0.5065^{*}$ & $-0.5806^{*}$ & $0.7993 *$ & $0.2629 *$ & $-0.5485^{*}$ & 0.1348 & $0.3313^{*}$ & $0.3560 *$ & 1.0000 & \\
\hline LD & $0.8648 *$ & $-0.7742 *$ & $0.2113^{*}$ & 0.0986 & 0.0065 & $0.4133^{*}$ & $0.2594^{*}$ & 0.1710 & 0.2369 & 1.0000 \\
\hline
\end{tabular}

Note: *Correlation is significant at 0.05 level (2-tailed)

**Correlation is significant at 0.01 level ( 2 tailed)

Table 4: Pearson Correlation for Islamic bank

\begin{tabular}{|c|c|c|c|c|c|c|c|c|c|c|}
\hline & CR & MGT & LEV & RSEC & REGCAP & LLP & FCOST & RWA & SIZE & LD \\
\hline CR & 1.0000 & & & & & & & & & \\
\hline MGT & $-0.4751 *$ & 1.0000 & & & & & & & & \\
\hline LEV & $0.4087^{*}$ & 0.2523 & 1.0000 & & & & & & & \\
\hline RSEC & 0.0973 & 0.1832 & 0.2085 & 1.0000 & & & & & & \\
\hline REGCAP & 0.0387 & 0.0923 & -0.1458 & -0.0025 & 1.0000 & & & & & \\
\hline LLP & 0.0928 & -0.0237 & -0.0479 & 0.1629 & 0.2823 & 1.0000 & & & & \\
\hline FCOST & -0.0469 & 0.1804 & 0.0545 & $-0.3089 *$ & $0.3167^{*}$ & 0.2051 & 1.0000 & & & \\
\hline RWA & $0.5940^{*}$ & 0.0884 & $0.8839 *$ & $0.2399 * *$ & 0.0385 & 0.0681 & 0.0769 & 1.0000 & & \\
\hline SIZE & 0.1618 & $0.3524^{*}$ & $0.6449 *$ & 0.1286 & $0.4061^{*}$ & -0.0113 & 0.1327 & $0.6701^{*}$ & 1.0000 & \\
\hline LD & $0.3954^{*}$ & -0.1935 & 0.1589 & $0.2483^{* *}$ & -0.0669 & 0.0027 & -0.1407 & 0.2160 & 0.0429 & 1.0000 \\
\hline
\end{tabular}

Note: *Correlation is significant at 0.05 level (2-tailed)

**Correlation is significant at 0.01 level ( 2 tailed) 
In conclusion, there was a significant relation between credit risk and the factor that influence risk in Islamic and conventional bank. Thus, the null hypothesis of no significant association between credit risk and the factor that influence risk was rejected at a 5 percent significant level.

Table 5: Result for Conventional and Islamic bank

\begin{tabular}{|c|c|c|}
\hline Variable & Conventional & Islamic \\
\hline \multirow[t]{2}{*}{ Constant } & -0.6985 & -0.2046 \\
\hline & $(0.3761)^{*}$ & $(0.0357)^{* * *}$ \\
\hline \multirow[t]{2}{*}{ MGT } & -0.2421 & -0.1306 \\
\hline & $(0.0418)^{* * *}$ & $(0.0404)^{* * *}$ \\
\hline \multirow[t]{2}{*}{ LEV } & -0.4282 & -0.8418 \\
\hline & $(0.1520)^{* * *}$ & $(0.2645)^{* * *}$ \\
\hline \multirow[t]{2}{*}{ RSEC } & -0.0799 & -0.0946 \\
\hline & $(0.0337)^{* *}$ & $(0.0389)^{* *}$ \\
\hline \multirow[t]{2}{*}{ REGCAP } & -0.0605 & 0.0787 \\
\hline & (0.0743) & $(0.3855)$ \\
\hline \multirow[t]{2}{*}{ LLP } & 0.4639 & 0.4841 \\
\hline & $(1.7216)$ & $(0.5858)$ \\
\hline \multirow[t]{2}{*}{ FCOST } & 0.7200 & -0.1530 \\
\hline & $(0.3960)^{*}$ & $(0.5516)$ \\
\hline \multirow[t]{2}{*}{ RWA } & -0.0005 & 0.2319 \\
\hline & (0.0019) & $(0.0378)^{* * *}$ \\
\hline \multirow[t]{2}{*}{ SIZE } & 1.8115 & 0.0073 \\
\hline & $(0.4849)^{* * *}$ & $(0.0056)$ \\
\hline \multirow[t]{2}{*}{ LD } & 0.1769 & 0.0243 \\
\hline & $(0.0438) * * *$ & $(0.0057)^{* * *}$ \\
\hline $\mathbf{N}$ & 189 & 144 \\
\hline $\mathbf{R}^{2}$ & 0.9942 & 0.9541 \\
\hline Adj. $R^{2}$ & 0.9919 & 0.9341 \\
\hline $\mathbf{F}$ & 441.6390 & 47.6496 \\
\hline $\mathbf{P}$ & 0.0000 & 0.0000 \\
\hline DW & 1.9272 & 2.2100 \\
\hline
\end{tabular}

Note:

Figure in parentheses is standard error value of the regression coefficient $* * *, * *, *$ denotes a significant level at $1 \%, 5 \%$ and $10 \%$ confidence level.

\section{Research Implication and Conclusion}

This paper attempts to fill the gap by examining the factors affecting credit risk in Islamic and conventional bank in Malaysia. The general objective of the study was to determine the factor affecting credit risk. The result shows that credit risk is an important factor for banking in managing risk. This paper used a regression model for examining the research question. This model shows that there is a significant positive relationship between funding cost, bank size, and loan to deposit with credit risk and negative significant relationship between management efficiency, leverage and risky 
loan sector with credit risk in conventional banks. While in Islamic bank only risk weight asset and proportion of loan to deposit are significant positive relationship with credit risk and management efficiency, risky loan sector and bank size are negative relationship with credit risk. From the finding suggest the implementation of successful credit risk management system bank should focus on several policy implications. The risks are very difficult to judge and quantify based on the analysis particular situation. For this reason, bank should have a stringent regulatory requirement. With this policy, the problem of credit risk regarding the regulatory will decrease and loss will be complete or partial can and arise in a number of circumstances. In fact, the effectiveness of credit risk management is very important in the banking system and gives them to increase their profitability and improve bank financial performance. Establishment of a comprehensive credit risk management system in both banking systems should be a prerequisite as it contributes to the overall risk management system of the bank. These papers only focus on internal factors of bank risk and in future research this area should include the external factor that can affect bank risk. Hence, further exploration regarding this aspect should need urgently.

\section{Corresponding Author}

Norazwa Ahmad Zolkifli @ Uda

Institute of Malaysian and International Studies (IKMAS)

Universiti Kebangsaan Malaysia

Malaysia

Email: norazwa76@gmail.com

\section{References}

Ahmad, N. (2003). Credit Risk Determinants: By Institutional Type. Paper presented at the Proceedings of Malaysian Finance Association Conference.

Ahmad, N. H., \& Ahmad, S. N. (2004). Key factors influencing credit risk of Islamic bank: A Malaysian case. The Journal of Muamalat and Islamic Finance Research, 1(1), 65-80.

Ahmad, N. H., \& Arif, M. (2004). Key risk determinant of listed deposit-taking institutions in Malaysia. Malaysian Management Journal, 8(1), 69-81.

Ahmad, N. H., \& Ariff, M. (2007). Multi-country study of bank credit risk determinants. International Journal of Banking and Finance, 5(1), 6.

Al-Saati, A.-R. (2003). The permissible Gharar (risk) in classical Islamic jurisprudence. Islamic Economics, 16(2), 3-19.

Aldoseri, M. (2012). Risk exposure of Islamic financial institutions: evidence from Gulf Co-operation Council countries| NOVA. The University of Newcastle's Digital Repository.

Al-Wesabi, H. A., \& Ahmad, N. H. (2013). Credit risk of Islamic banks in GCC countries. International Journal of Banking and Finance, 10(2), 8, 120-136. http://epublications.bond.edu.au/ijbf/vol10/iss2/8

Angbazo, L. A., Mei, J., \& Saunders, A. (1998). Credit spreads in the market for highly leveraged transaction loans. Journal of Banking \& Finance, 22(10), 1249-1282. https://doi.org/10.1016/S0378-4266(98)00065-X

Annual Review. (2009). Malaysia's Economic Outlook 2009-2020. Kuala Lumpur: RAM Holding Berhad.

Ariff, M. (1988). Islamic banking. Asian-Pacific Economic Literature, 2(2), 48-64. 
Beaver, W., Eger, C., Ryan, S., \& Wolfson, M. (1989). Financial reporting, supplemental disclosures, and bank share prices. Journal of Accounting Research, 27,157-178. DOI: 10.2307/2491230

Berger, A. N., \& DeYoung, R. (1997). Problem loans and cost efficiency in commercial banks. Journal of Banking \& Finance, 21(6), 849-870. https://doi.org/10.1016/S0378-4266(97)00003-4

Borham, A.J., (2009). Banking Industry And Islamic Finance. Kuantan, Pahang: Universiti Malaysia Pahang.

Bhatti, I., \& Misman, F. N. (2010). Risks Exposure in Islamic Banks: A Case Study of Bank Islam Malaysia Berhad (BIMB). Paper presented at the Australian Centre for Financial Studies-Finsia Banking and Finance Conference.

Carey, M., \& Stulz, R. M. (2005). The risks of financial institutions: National Bureau of Economic Research.

Corsetti, G., Pesenti, P., \& Roubini, N. (1998). What caused the Asian currency and financial crisis? Part I: A macroeconomic overview: National Bureau of Economic Research.

Hanif, M., Tariq, M., Tahir, A., \& Momeneen, W. U. (2012). Comparative performance study of conventional and islamic banking in Pakistan. International Research Journal of Finance \& Economics(83).

Hassan, M. K. (1993). The off-balance sheet banking risk of large US commercial banks. The Quarterly Review of Economics and Finance, 33(1), 51-69.

Hassan, M. K., \& Bashir, A.-H. M. (2003). Determinants of Islamic banking profitability. Paper presented at the th ERF Annual Conference.

Hussain, H. A., \& Al-Ajmi, J. (2012). Risk management practices of conventional and Islamic banks in Bahrain. Journal of Risk Finance, The, 13(3), 215-239. http://dx.doi.org/10.1108/15265941211229244

Gujarati, D. N. (2003). Basic Econometrics. New York: McGraw-Hill.

Kahf, M. (2005). Basel II: implications for Islamic banking. Paper presented the 6th International Conference on Islamic Economics and Banking, Jakarta.

Khan, T., \& Ahmed, H. (2001). Risk management: an analysis of issues in Islamic financial industry: Islamic Development Bank, Islamic Research and Training Institute.

Lobo, G. J., \& Yang, D.-H. (2001). Bank Managers' Heterogeneous Decisions on Discretionary Loan Loss Provisions. Review of Quantitative Finance and Accounting, 16(3), 223-250. DOI: 10.1023/A:1011284303517

Madura, J., Martin, A. D., \& Taylor, D. A. (1994). Determinants of implied risk at depository institutions. Applied Financial Economics, 4(5), 363-370. http://dx.doi.org/10.1080/758536474

Musyoki, D., \& Kadubo, A. S. (2012). The impact of credit risk management on the financial performance of Banks in Kenya for the period. International Journal of Business and Public Management, 2(2): 72-80

Park, S. (1997). Risk-taking behavior of banks under regulation. Journal of Banking \& Finance, 21(4), 491-507. https://doi.org/10.1016/S0378-4266(96)00050-7

Rahman, A. A. (2010). Financing structure and insolvency risk exposure of Islamic banks. Financial Markets and Portfolio Management, 24(4), 419-440. DOI: 10.1007/s11408-010-0142-x

Rekha, A., \& Kotreshwar, G. (2005). Risk Management In Commercial Banks (A Case Study Of Public And Private Sector Banks). Paper presented at the Ninth Capital Market Conference.

Ruhul Salim, Amir Arjomandi \& K. Hervé Dakpo (2016): Banks' efficiency and credit risk analysis using by-production approach: the case of Iranian banks, Applied Economics, Applied Economics, 49(30), 2974-2988. DOI: 10.1080/00036846.2016.1251567 
Shrieves, R. E., \& Dahl, D. (1992). The relationship between risk and capital in commercial banks. Journal of Banking \& Finance, 16(2), 439-457. https://doi.org/10.1016/0378-4266(92)90024-T

Sundararajan, V., \& Errico, L. (2002). Islamic financial institutions and products in the global financial system: key issues in risk management and challenges ahead (Vol. 2): International Monetary Fund.

Vaaler, P. M., \& McNamara, G. (2004). Crisis and competition in expert organizational decision making: Credit-rating agencies and their response to turbulence in emerging economies. Organization Science, 15(6), 687-703. http://dx.doi.org/10.1287/orsc.1040.0089

Vitria, I. (2008). The relationship between Islamic financing with risks and performance of commercial banks in Indonesia.

Waemustafa, W., \& Sukri, S. (2015). Bank specific and macroeconomics dynamic determinants of credit risk in Islamic banks and conventional banks. International Journal of Economics and Financial Issues, 5(2).

Wooldridge, J. M. (2002). Econometric analysis of cross section and panel data. United State of America: Massachusetts Institute of Technology. 